ments with existing plants. Some controversial matters arose in the discussion of the Third Report of the Fuel Economy Committee, which was presented by Prof. Bone. The report includes a memorandum by Prof. Louis urging improvements in the collection and presentation of mining statistics, and these recommendations have been adopted by the Committee. The Committee further disagreed with the policy of the Fuel Research Board in regard to the regulation of the quality of gas, and insisted on the importance of the limitation of inert constituents and sulphur. The hope was expressed that a further opportunity would be afforded to the Committee to submit its views to the Board of Trade before the matter was finally settled. The policy of the Fuel Research Board was defended by a later speaker, and references were made in the discussion to the use of colloidal fuel and to the recovery of ethylene from coke-oven gas. The Section asked for the reappointment of the Committee, which has done valuable work in directing public attention to the urgent national need for fuel economy. An allied subject was dealt with by Dr. Owens in his paper on the measurement of smoke pollution as carried out by a Committee of the Meteorological Office. The methods of determining acidity in air have been improved, but a good method of estimating the amount of acidity borne by the suspended solid particles is still lacking.

The discussion on lubrication covered similar ground to that of recent meetings of technical societies. Messrs. Wells and Southcombe described the influence of small quantities of free fatty acids in lubricating oils, and Dr. Dunstan directed attention to the present ignorance of the chemical nature of mineral oils. The mode of action of acids on these oils is almost completely unknown. Mr. Tizard regarded lubrication as dependent on the formation of an adsorbing layer on the surface of the metal bearing, and mentioned curious results obtained in determining surface tension between mercury and oils by the drop method. Castor oil and glycerol have about the same viscosity, but the former is a good lubricant and the latter worthless. Mercury drops falling through castor oil remain intact at the bottom of the vessel like lead shot, whilst in glycerol they coalesce immediately.
Mr. Vogel's paper on tungsten described the methods employed in the manufacture of the metal at Widnes, and included an interesting account of the steps taken by the steelmakers of this country, when the outbreak of war deprived them completely of supplies of this most essential metal, to meet the requirements of the industry, with such success that all the tungsten needed is now manufactured at home, whilst a surplus remains for export, the quality being superior to that of the metal used before the war. Prof. Desch gave an account of the preparation and properties of ductile tungsten, and directed attention to the remarkable properties of the metal in the drawn state, a complete theoretical explanation of which is still lacking. Mr. Field's paper claimed great advantages for the electrolytic method of extracting zinc over the usual distillation process, and urged its more widespread adoption. Two short analytical papers were presented by Dr. Stanford, and the last session closed with an exceedingly interesting account by Prof. Jaeger, of Groningen, of his determinations of the surface tension and electrical conductivity of organic liquids and fused salts over the remarkably wide range of $-100^{\circ} \mathrm{C}$. to $+1600^{\circ} \mathrm{C}$.

The report of the Committee on Absorption Spectra, which was taken as read and not discussed, consisted mainly of an exposition by Prof. Baly of his theory of absorption. This paper might have furnished the basis of a good discussion, as the physical theory involved is novel, and criticism from both the chemical and the physical sides should be expected. Whilst numerous papers on the use of atomic frequencies and of the idea of quanta have been published in recent years, there has been no thorough discussion of such views, and most chemists have allowed the communications to pass without submitting them to any rigorous scrutiny, so that it is uncertain how far the new ideas are likely to meet with acceptance.

Cardiff afforded many opportunities for the inspection of chemical industries of varied kinds, and the Sectional excursions, which were well attended, included visits to iron- and steel-works, copper-smelting works, tinplate works, gasworks, and a rubber factory.

\title{
The Lakher Head-hunters of Upper Burma.
}

$A^{T}$ the opening meeting of the session of the Royal Anthropological Institute, held on Tuesday, October 26, Prof. F. G. Parsons, vice-president, in the chair, Mr. Reginald A. Lorrain, of the Lakher Pioneer Mission, read a paper on "Lakherland, the Home of the Head-hunters."

Lakherland lies on the border of Upper Burma, and is some twenty days' march from civilisation. The Lakhers, who are practically unknown to the civilised world, are of the Mongolian type, and chocolate-coloured. While the men wear a small loincloth only, save for a large blanket thrown round them in the colder evenings, the women wear more clothing, their garments consisting of a piece of cloth for a skirt reaching down to the ankles, while a breast-jacket nearly covers the upper portion of the body. This jacket is open at the back in order that the heavy loads the women carry should not wear out the garment. The men allow their hair to grow long, but it is fastened in a large knot on the top of the head with long brass pins. A plume of horsehair is entwined in the head-cloth to show that the wearer has taken a head. The children run about in a nude condition up to the age of ten or twelve years.

No. 2663 , VOL. IO6]
The Lakhers are skilled smiths, although their tools and appliances are of the simplest character. The forge consists of three slabs of stone, and the bellows are hollowed trunks of trees in which is fitted a plunger consisting of a circular disc fitted to a handle, feathers being attached to the rim of the disc to make the plunger practically airtight. Pottery is made by the women without a wheel. The clay, which is obtained from the white-ant heaps, is moulded between a stone held inside the pot and a hammer with rope wound over the head.

An interesting feature in a dance described by $\mathrm{Mr}$. Lorrain was that the ceremonial headdress of the chief for this occasion, which is handed down from father to son, was always worn by the chief's daughter.

The dead are buried in graves immediately outside the dwelling-houses. The grave consists of a hole about $4 \mathrm{ft}$. square, but the body is placed in a small, sloping trench or tunnel underground excavated from one side of this hole. The body is pushed into the tunnel feet first, the cavity then being closed with a stone. An ornamental wooden pole, with projections or ears which distinguish by their number the sex of the deceased, is erected over the grave. Outside 
the village decorated memorial poles are erected. In the example described by Mr. Lorrain, one of the poles bore the horsehair plume denoting that the deceased had taken heads and the tail-feather of a cock denoting that he had carried off another man's wife, while on another pole was the skull he had taken. A third small pole showed projecting points, each representing a slave he had carried off when making raids. The animals which had fallen to his spear in the chase were represented by stones round the foot of the poles. A large, flat stone was possibly a sacrificial slab. On one side was placed a row of flat staves representing the deceased's wives.

Great value is attached to the heads of animals taken in the chase and to the heads of human beings taken in tribal wars and raids, as the possession of such is believed to give the owner not only power over the victims in the "world to come," but also ensures a permit into Paradise after the death of the one who has obtained a full set of heads. Sometimes the marriage price of a maiden consisted in part of a number of such heads of human beings, and this led to young men entering into raids upon their near or distant neighbours.

By religion the Lakhers are animists, but it would be more correct to sav that they appeased rather than worshipped these spirits, which are believed to be the authors of all evil. A large tree in the centre of the village was held to be the abiding place of the most powerful spirit. At the foot of this tree was the sacrificial stone upon which cocks and pigs were sacrificed.

In the discussion which followed the paper Mr. Lorrain, in replying to certain queries raised by Col. Shakespeare, stated further that there were wellmarked social distinctions between the clans. The headship of the village could be held only by the members of about six clans. Next in grade to these were the aristocratic clans, also about six in number, who could not hold the headship of the village. The lower classes comprised two grades, an upper of ten to fifteen clans and a lower of about thirty clans. Below these were the slaves. The headship of the village descended from the father to the youngest son of the chief legitimate wife: other sons became headmen of outlying villages. Mr. Lorrain had not found any regular institution of feasts similar to those held among the neighbouring Lushai, which, when given in a certain progression in the number and character of the victims, bring the giver honour in this world and favour in the world to come. $\mathrm{He}$ had found, however, one instance of a house in which the door had a rounded instead of a square top. The exact significance of this he had not been able to ascertain beyond that it was a privilege connected in some way with a special sacrifice.

\section{Meteors of the Season.}

THE November meteors are due tc return on November $\mathrm{I}_{4}$ and $\mathrm{I}_{5}$, and, though no abundant display may be expected, Mr. W. F. Denning thinks that the shower is likely to prove fairly conspicuous. The parent comet of the meteors must have been in aphelion in 1916, and is now situated between the orbits of Saturn and Uranus, so that whatever meteors may appear this year riust be at a vast distance from the cometary nucleus of the shower. The whole orbit, however, contains meteoritic particles, and observations during last century prove that this system re-appears annually at the middle of November. It is fortunate that the moon will be absent from the sky after the rising of the Leonid radiant, which occurs at about Io. I5 p.m. NO. 2663 , VOL. IO6] on November ${ }^{15}$. Probably the meteors will be far more abundant after midnight, when the radiant at $150^{\circ}+23^{\circ}$ has attained a fairly good altitude.

These November meteors belong to the swift class, moving at the apparent velocity of 44 miles per second, and, like the Perseids of August, they include flashing fireballs of the largest kind intermingled with the smallest shooting stars.

An abundant shower of meteors was observed between October 30 and November 5 , and quite a large number of fireballs were seen. The meteors belonged to a radiant point in Taurus and a few degrees southwest of the Hyades, at about $59^{\circ}+12^{\circ}$. There was also another shower situated in Aries at $43^{\circ}+22^{\circ}$, which furnished a considerable number of meteors. These were slow-moving, brilliant objects, and have usually traversed long flights.

Both these showers were well observed by Miss A. Grace Cook from Stowmarket during a series of careful and prolonged meteoric observations between October 30 and November 4. Mr. F. Sargent at the University Observatory, Durham, also witnessed the fall of a number of meteors on October 30 and November 5. At Bristol Mr. Denning saw some of the meteors, and one of them, on October 3o, about 7.I4, was also observed by Mr. F. Sargent. The real path of this object was from about 77 to 55 miles in height, and its luminous course r ro miles at a velocity of about 24 miles per second. The radiant point was at $60^{\circ}+14^{\circ}$.

A very brilliant member of the same shower appeared on November 4 at $6 . x \mathrm{I}$, and came under observation by Miss A. Grace Cook at Stowmarket and by others at Bristol and Ilford. It had an ex: tremely long path, and afforded a grand spectacle to many observers in the south of England. This was also a Taurid, and it traversed a horizontal course of about 235 miles at a height of about 63 miles from over the sea, about 40 miles east of Southwold, to over Somerset about 20 miles south of Bath. This shower of Taurid meteors is well known, but its recent display, like that on November 2, I886, was of a rather exceptional character.

\section{Heredity and Social Fitness.}

$D^{R}$. WILHELMINE E. KEY has made (Carnegie Institution, Washington, Publication 296, 1920, pp. I02) a careful study of differential mating in a Pennsylvania family. The study comprises 1822 in. dividuals, nearly half of whom are in the direct line of descent from two pairs of German immigrants of more than a century ago. The remainder were considered in connection with the strains into which the descendants of these couples married. The research began with four young people, patients at the Institution for the Feeble-minded of Western Pennsylvania, and was followed into intricate networks of stocks. Some of the general results may be outlined. (r) The behaviour in inheritance of such qualities as far-sightedness, perseverance, and push indicates that the occurrence of these traits is due to a segregation of their determiners. (2) There was a decided decrease in fecundity in all lines, but not more marked in the socially inefficient than in the efficient. On the other hand, the survival ratios increase for the successive generations of the efficient lines, while they decrease for the inefficient lines, thus illustrating Nature's method of eliminating the unfit. (3) In migration the more efficient push into new areas, the less efficient tend to settle down. (4) The reactions of the degenerate members show that the variations in efficiency are due not to adverse conditions, or to 